\title{
養液イオン濃度調製プログラムを使用したキュウリの栽培
}

\author{
久保田 豊 ${ }^{1,2}$ - 位田晴久 ${ }^{1} \cdot$ 東 順正 $^{1 *}$ - 中原光久 ${ }^{3}$ \\ 1宮崎大学農学部 889-2192 宮崎市学園木花台西 1-1 \\ 2鹿児島大学大学院連合農学研究科 \\ 3九州電力 (株)総合研究所農業電化試験場 849-0922 佐賀市高木瀬東 1-10-1 \\ *佐々木食品工業(株） 879-0615 大分県豊後高田市大字界 276
}

\section{Hydroponic Culture of Cucumber Using the Software for Automatic Ion Control of Nutrient Solutions}

\author{
Yutaka Kubota ${ }^{1,2}$, Haruhisa Inden $^{1}$, Yorimasa Higashi ${ }^{1 *}$ and Teruhisa NAKAHARA ${ }^{3}$ \\ ${ }^{1}$ Faculty of Agriculture, Miyazaki University, Miyazaki 889-2192, Japan \\ ${ }^{2}$ United Graduate School of Agricultural Sciences, Kagoshima University \\ ${ }^{3}$ Agricultural Electrification Testing Center, Kyushu Electric Power Co., Inc., Takagise-Higashi, Saga 849-0922, Japan \\ *Sasaki Foods Co., Ltd, Bungotakada, Ohita, 879-0615, Japan
}

\begin{abstract}
Using the developed software for the automatic ion control of nutrient solution('IonAdjuster'), the hydroponic culture of cucumber (Cucumis sativus L.) was carried out. It was compared with the practical culture managed by $\mathrm{EC}$ value of the nutrient solution. In the ion concentration control method using 'IonAdjuster', each ion concentration of $\mathrm{NO}_{3}-\mathrm{N}, \mathrm{NH}_{4}-\mathrm{N}, \mathrm{PO}_{4}-\mathrm{P}, \mathrm{K}$, $\mathrm{Ca}, \mathrm{Mg}$ could be maintained around the set value except for a short while. In the EC control method, each ion concentration greatly fluctuated, this meant it shifted considerably from the initial value in the later stage of cultivation, and the ionic balance also collapsed. The value of $\mathrm{pH}$ decreased gradually as usual in the cucumber solution culture, however, adding the $\mathrm{pH}$ stabilization routine to the ion concentration control method could solve it. Though there was a little difference in early yield and total yield between the two methods, the first class fruit rate rose about $15 \%$ in the ion concentration control method, and the marketable yield also increased. In addition, the system using 'IonAdjuster', there are also some effects of environmental loading reduction by decreasing waste nutrient solution at renewal, fertilizer reduction, and labor saving of solution preparation, so it seems to be useful.
\end{abstract}

Keywords : hydroponics, nutrient solution, ion concentration, software program, cucumber

\section{緒言}

養液栽培に扔ける一般的な培養液管理法は専ら電気伝 導度 $(\mathrm{EC})$ を指標として行われ, 長期間の栽培で組成が 変化することには, 定期的な培養液の全量交換により対

2001 年 1 月 16 日受付

2001 年 2 月 7 日受理
応している.しかし昨今の環境に対する意識の向上にと もない, 全量交換時の培養廃液による地下水の $\mathrm{NO}_{3}-\mathrm{N}$ イオン污染などに対する社会の目は厳しくなりつつある。 すでにヨーロッパでは規制が行われており1)，日本でも 遠からず実施されると考えられる。これらの規制に対処 するため培養液のリサイクルを行うことが考えられ，各 種の方法が試みられている ${ }^{2)}$. 筆者らはこの問題に対し 培養液のオートサンプリング, 自動分析, 各濃厚肥料溶 
液の自動注入，などの自動化を視野に入れ，長期間にわ たり培養液の全量交換無しに培養液の組成や濃度を維持 するソフトウェアであるIonAdjuster(養液イオン濃度 調製プログラム)を開発し，評価・改良を行ってきた ${ }^{3 \sim 6)}$.

本報では手動サンプリング, 肥料の手動注入と併用し てこのソフトウェアでキュウリを栽培し, 培養液中の各 イオン濃度の変化や植物体に及ぼす影響を従来の EC に 基づく制御法と比較し検討した結果について報告する.

\section{材料および方法}

\section{栽培方法}

キュウリ (Cucumis sativus L.) 品種 ‘永緑' 丸種)を供 試した。 1999 年 10 月 4 日に $25^{\circ} \mathrm{C}$ に設定した温度勾配 恒温器 (日本医化器械, $\mathrm{AD}-100)$ で 24 時間催芽処理を 行った後，バーミキュライト $2:$ パーライト $1(\mathrm{v} / \mathrm{v}) を$ 入れた育苗箱 $(33 \times 47 \times 8 \mathrm{~cm})$ に播種し, 昼温 $(8: 00$ $20: 00) 28^{\circ} \mathrm{C}$, 夜温 $(20: 00-8: 00) 18^{\circ} \mathrm{C}$ で管理した。出 芽後, 育苗箱を自然条件のビニルハウスへ移した. 10 月 15 日に山崎キュウリ処方7)培養液を入れた容器に移 植し, 本葉が 3 枚展開するまで湛液育苗した. 11 月 2 日にシーアイ化成 SS 式果菜用ベッドを湛液用に改造し たもの $(400 \times 36 \times 21 \mathrm{~cm}$ ，地上高 $62 \mathrm{~cm} ， 4$ 列 $)$ に株間 50 $\mathrm{cm}, 1$ ベッドあたり 7 個体定植し, 循環式湛液水耕山崎 キュウリ処方で栽培を行った。培養液量は各区(ベッ

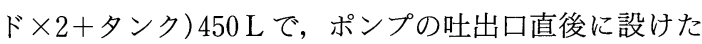
バルブを調整し培養液の一部をタンク内へ落下させるこ とでタンク内培養液の溶存酸素濃度を保った．整枝法は 子づるつる下げ誘引とし，18 節で摘心した．収穫した 果実は外観より, $\mathrm{A}$ 品(曲がりが果実半径以下), $\mathrm{B}$ 品 (曲がりが果実直径以下)，C品(生理障害果)の 3 段階に 分けた。

\section{培養液管理}

培養液制御法として，筆者らが開発した IonAdjuster (養液イオン濃度調製プログラム) ${ }^{6}$ に改良を加えたもの (Fig. 1) によるイオン濃度制御区と, その対照として慣 行の EC 制御区の 2 区を設けた. IonAdjuster の改良点 は主に $\mathrm{pH}$ に関する部分である. 植物体に吸収され, 組 成基準より不足した各イオンの濃度を上昇させるため肥 料を添加する場合, 使用する肥料の種類がある程度以上 になると，その組み合わせと添加量の回答は無数に近く 存在することになる. IonAdjusterにおいてはExcel (マイクロソフト)に装備されているソルバーを利用し, その中から設定した複数の条件を満たし，かつ特定の変 数が最大，最小もしくは定数に一番近くなる組み合わせ を回答として算出する.この設定する複数の条件の中に，

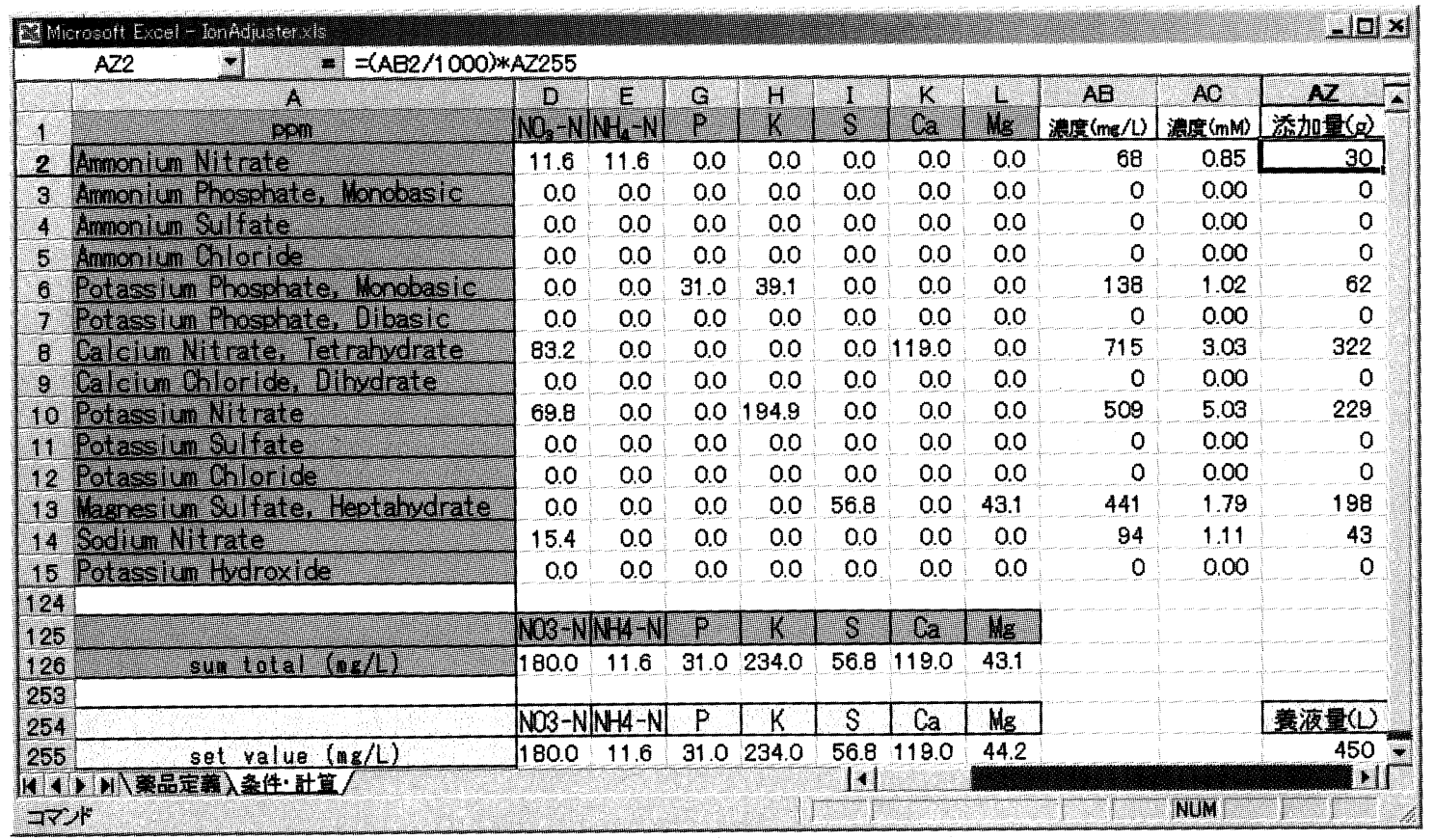

Fig. 1 Setting and calculation table of IonAdjuster on November 2, 1999. The volume of chemicals to be added is shown in $\mathrm{AZ} 2$ to $\mathrm{AZ} 15$ cells. 
Table 1 Nutrient solution management of the ion concentration control method

\begin{tabular}{ccccccc}
\hline \hline \multirow{2}{*}{$\begin{array}{l}\text { Adjustment } \\
\text { date }\end{array}$} & \multicolumn{5}{c}{ Set value of ion concentration $\left(\mathrm{mg} \cdot \mathrm{L}^{-1}\right)$} \\
\cline { 2 - 7 } & $\mathrm{NO}_{3}-\mathrm{N}$ & $\mathrm{NH}_{4}-\mathrm{N}$ & $\mathrm{PO}_{4}-\mathrm{P}$ & $\mathrm{K}$ & $\mathrm{Ca}$ & $\mathrm{Mg}$ \\
\hline 2 Nov. & 182 & 14 & 31 & 234 & 140 & 48 \\
5 Nov. & 182 & 14 & 31 & 234 & 140 & 48 \\
10 Nov. & 182 & 14 & 31 & 234 & 140 & 48 \\
15 Nov. & 182 & 14 & 31 & 234 & 140 & 48 \\
18 Nov. & 182 & 14 & 31 & 234 & 140 & 48 \\
2 Nov. & 182 & 18 & 31 & 345 & 210 & 48 \\
26 Nov. & 182 & 28 & 31 & 345 & 210 & 48 \\
30 Nov. & 182 & 28 & 31 & 345 & 210 & 48 \\
6 Dec. & 182 & 28 & 31 & 345 & 210 & 48 \\
9 Dec. & 182 & 28 & 31 & 345 & 210 & 48 \\
13 Dec. & 182 & 28 & 31 & 345 & 210 & 48 \\
16 Dec. & 182 & 28 & 31 & 345 & 210 & 48 \\
20 Dec. & 182 & 28 & 31 & 345 & 210 & 48 \\
26 Feb. & 182 & 28 & 31 & 345 & 210 & 48 \\
28 Dec. & 182 & 28 & 31 & 345 & 210 & 48 \\
31 Dec. & 182 & 28 & 31 & 345 & 170 & 48 \\
5 Jan. & 182 & 28 & 31 & 345 & 170 & 48 \\
\hline
\end{tabular}

添加する肥料全量中のイオンが “ $\mathrm{H}^{+}=\mathrm{OH}^{-”}$ となる条 件を付け加えた。この条件は正確には $\mathrm{pH}$ の制御をでき るものではないが, 少なくとも極端な $\mathrm{pH}$ の変動はある 程度制限できると考えられたからである，培養液組成の 基本設定としては前作での栽培結果と生育ステージによ る肥料吸収量の変化を踏まえ，イオン制御区, EC 制御 区共に山崎キュウリ処方 $\left(\mathrm{NO}_{3}-\mathrm{N} 182, \mathrm{NH}_{4}-\mathrm{N} 14, \mathrm{PO}_{4}-\right.$ $\left.\mathrm{P} 31, \mathrm{~K} 234, \mathrm{Ca} 140, \mathrm{Mg} 48, \mathrm{SO}_{4}-\mathrm{S} 64 \mathrm{mg} \cdot \mathrm{L}^{-1}\right)$ とし, 微 量要素として大塚八ウス 5 号 $(\mathrm{Fe} 2.85, \mathrm{~B} 0.32, \mathrm{Mn} 0$. 77, Zn 0. 04, Cu 0. 02, Mo 0. $\left.022 \mathrm{mg} \cdot \mathrm{L}^{-1}\right)$ を用いた. EC 制御区では培養液の $\mathrm{EC}$ 值が常に $2.2 \mathrm{dS} \cdot \mathrm{m}^{-1}$ となるよ う自動管理機 (シーアイ化成, AS-3)で制御した。イオ ン制御区では週に $1 \sim 2$ 回培養液をサンプリング・分析 し, それぞれのイオン濃度をプログラムに入力し, 得ら れた回答に基づいて薬品を注入し制御を行った。前作で の栽培結果と生育時期による吸収量の変化を踏まえ設定 イオン濃度を適宜変更した(Table 1). 制御対象イオン は硝酸態窒素, アンモニア態窒素, リン, カリウム, マ グネシウム, カルシウムとした. イオン濃度検出はアニ オンは比色定量法, カチオンはイオンクロマトグラフィ 一法(東ソー, EC 8020 および TSKgel IC-Cation I/II) を用いた。

\section{結 果}

\section{培養液中のイオン濃度}

硝酸態窒素 : イオン制御区では $11 / 30$ まで目標值を上
回って推移したが，それ以降は 1 週間ごとの調整により ほほ目標値に復帰した (Fig. 2). EC 制御区では栽培中 期以降は組成基準值を上回って推移した。

アンモニア態窒素：イオン制御区では $11 / 22$ から $12 / 13$ までは目標値を下回ったが, それ以外の期間はほぼ目標 值に復帰した. EC 制御区では栽培中期以降はほほ 0 に 近い值で推移した.

リン：イオン制御区では栽培期間を通じて調整によりほ ぼ目標值に復帰した。 EC 制御区では若干の濃度変動が 栽培期間を通じてみられた。

カリウム：イオン制御区では栽培後期の一時期を除いて 調整によりほぼ目標值に復帰した。 EC 制御区では $11 /$ 10 から $11 / 26$ の間は組成基準值よりもかなり低い值と なった.

カルシウム：イオン制御区では $11 / 15$ までは目標值の変 更に伴うばらつきがみられたが，それ以降は調整により ほほ目標値に復帰した。 また栽培後期になるに従い植物 体の吸収量が増加する傾向がみられた。 EC 制御区では 11/15 以降組成基準值よりもかなり高い值で推移した。 マグネシウム：イオン制御区では $11 / 10$ 以外は調整によ りほほ目標值に復帰した。 EC 制御区では $11 / 5,11 / 10$ に組成基準值を大きく上回った後すぐに減少し，その後 は組成基準值を超えたまま増加する傾向がみられた。 pH

イオン制御区では $11 / 22$ まではソルバー中で $\mathrm{pH}$ を調 整する条件の優先順位を各イオン濃度の調整条件より下 位に設定していたため, pH が低下し続けた (Fig. 3). 

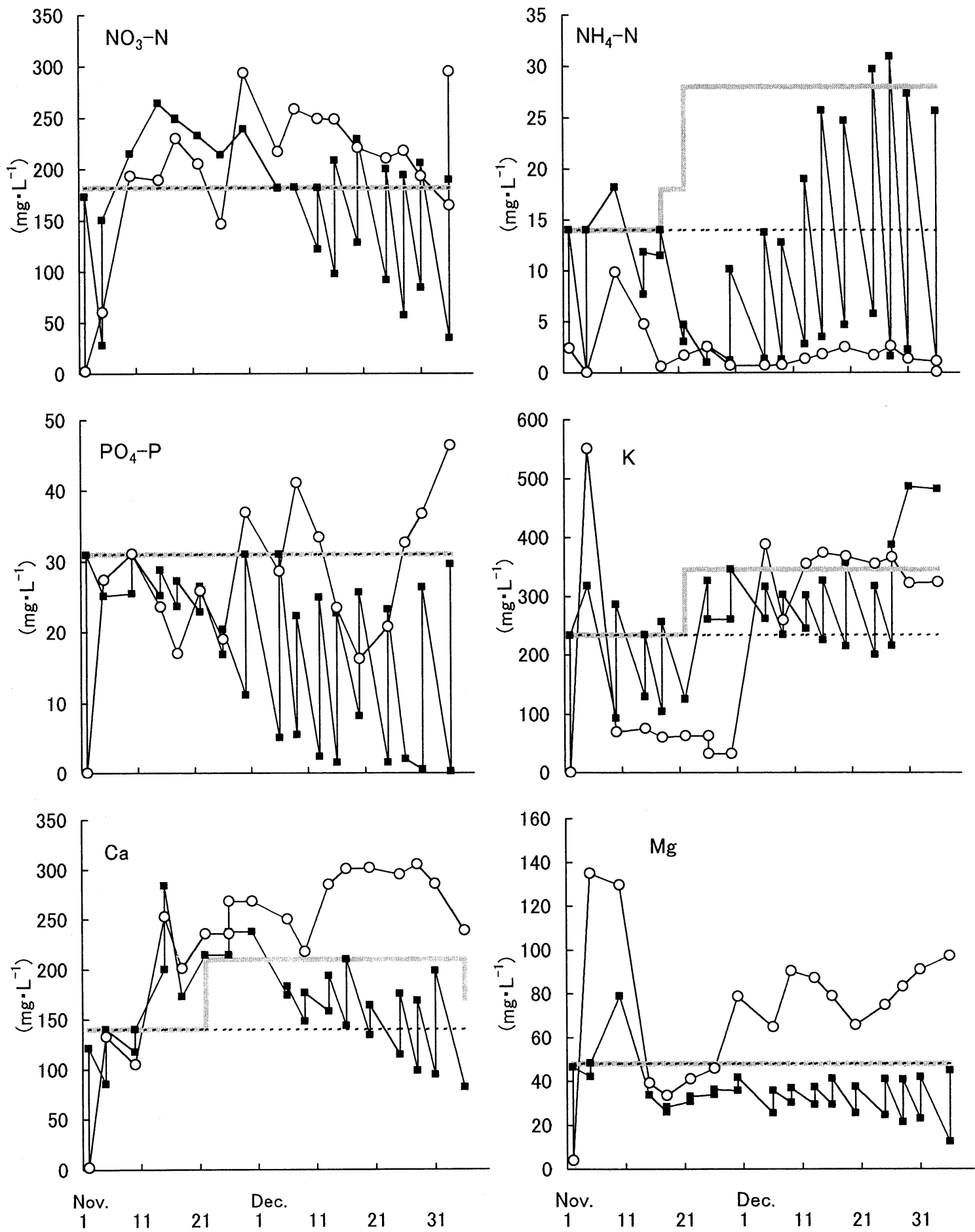

Fig. 2 Changes in concentration of major elements in the nutrient solution of ion control method and EC control method. Gray line shows the set value of concentration of each element of the ion control method. Dotted line shows the initial value of concentration of each element of the EC control method. - Ion control method $-\mathrm{O}-$ EC control method 


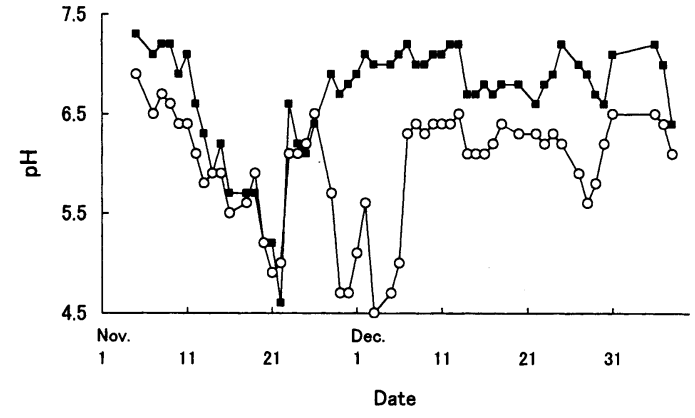

Fig. 3 Changes in $\mathrm{pH}$ values in the nutrient solution of ion control method and EC control method.

- Ion control method

- EC control method

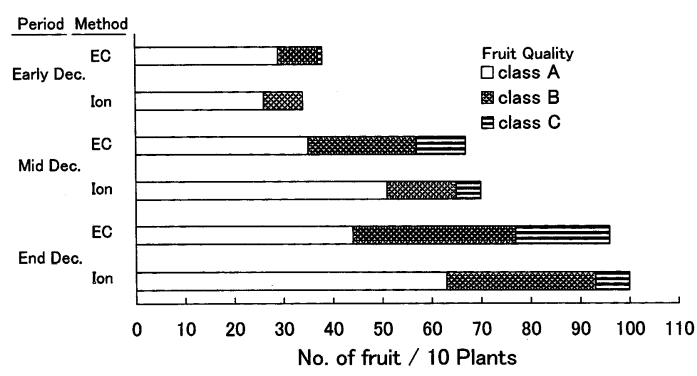

Fig. 4 Effect of the EC control method and the ion control method on fruit quality and yield by growing stage.

$11 / 22$ に $\mathrm{NaOH}$ を添加して $\mathrm{pH}$ の回復を図ると共に, プログラムを見直し $\mathrm{pH}$ 調整条件の優先順位を最上位に 移動させた。 その結果, 11/23 以降は $\mathrm{pH}$ はほほ 6.5 か ら 7.0 の範囲で安定して推移した. EC 制御区でも $\mathrm{pH}$ の低下がみられ，11/23，12/7, 12/30 の 3 回 $\mathrm{NaOH}$ を添 加して $\mathrm{pH}$ の上昇を図ったが，11/26 から $12 / 6$ までの 期間は $\mathrm{pH} 4.7$ 前後で推移し, その後も 6.0 前後とイオ ン制御区よりも低い値で推移した。

\section{収穫果数, 果実品質}

イオン制御区と $\mathrm{EC}$ 制御区の間で総収穫果数・各期収 穫果数に差はみられなかった。 A 品割合は収穫初期に は両区に差はなかったが, 中期, 後期ではイオン制御区 の方が高くなった。総収穫果数に対する総 $\mathrm{C}$ 品果割合 はイオン制御区の方が $9.0 \%$ 低く, 総 $\mathrm{A}$ 品果割合は 14. 9\% 高くなった(Fig. 4).

\section{考察}

キュウリの養分吸収量は作型・栽培環境などによって 異なるが，一般的に生育量に比例して増大する。また収
穫期になると $\mathrm{K} や \mathrm{P}$ の吸収量が多くなる。これは培養 液中の $\mathrm{K}, \mathrm{P}$ の吸収が容易であるのと同時に, キュウリ のように生育中期以降に果実が連続して収穫される作物 では果実中の存在比が高い K が多く吸収されるためで ある。その他キュウリでは生育後期に培養液中の $\mathrm{Ca}$, $\mathrm{Mg}$ の濃度が上昇する例が多く, 培養液の $\mathrm{pH}$ と無関係 に $\mathrm{NH}_{4}-\mathrm{N}$ を優先的に吸収するとされている ${ }^{8)}$.さらに キュウリの $\mathrm{NO}_{3}$ と $\mathrm{NH}_{4}$ の比率の好適範囲は $\mathrm{NH}_{4}$ が $\mathrm{NO}_{3}$ の $1 / 3$ 以下であるという報告もある ${ }^{9)}$. キュウリの 養分吸収にはこのような特徵があるため, 培養液中のイ オンバランスや $\mathrm{pH}$ が変動し，さまざまな生理障害が発 生する.

イオン制御区において $\mathrm{PO}_{4}-\mathrm{P}$ は栽培前半は $\mathrm{EC}$ 制御 区とほほ同様の変動パターンを示したが，栽培後期には 植物体の吸収が $\mathrm{EC}$ 制御区より多く, 変動が大きくなっ た. $\mathrm{K}$ は栽培初期に EC 制御区での濃度が大きく落ち込 んだがイオン制御区ではほほ設定值を維持した。Ca, $\mathrm{Mg}$ はイオン制御区では生育後期も吸収されていた。こ れはイオンバランスが良く，カチオン同士の拮抗作用が 起きにくかったためではないかと考えられる. 前作の結 果より $\mathrm{NH}_{4}-\mathrm{N}$ の設定值を吸収が多くなると考えられる 中期以降に高くしたが，植物体の吸収が予想以上に早く 設定值の半分以下の濃度となった。しかし EC 制御区と 比較すると植物体の要求に応えられたと考元られる。イ オン制御区では 1 週間毎の調整でおおお称設定したイオ ン濃度を保つことができた。キュウリ栽培における養液 の $\mathrm{pH}$ は $6.0 \sim 6.5$ が最適で, $5.0 \sim 7.0$ の範囲なら生育 に影響がないとされている。本実験の後半ではプログラ ムの改良により $\mathrm{pH}$ が安定化するようにしたが，まだ完 全なものではなく, アルカリ性薬品の添加を考慮する必 要があると思われる。これは補給するイオンのうち $\mathrm{NO}_{3}-\mathrm{N}$ が大きく不足した場合，一般的な肥料塩だけで は不足分を補充することができず，本りフトウェアでは $\mathrm{NaNO}_{3}$ を大量に補充する回答が示されるためである. ナトリウムイオンは他のイオンに比べて植物体の吸収量 は非常に少なく，培養液調製から時間が経過するに従い 培養液中の全イオン中に占める割合が増加する。その結 果ナトリウムイオンを含めたカチオンが過剩に存在する こととなったことが $\mathrm{pH}$ 低下の一因と考えられる。池田 らの報告 ${ }^{100}$ によれ゙施与する窒素分のうち，アンモニア 態窒素の比率が高くなると $\mathrm{pH}$ 低下の傾向が強くなる.

これらの問題には現在はソフトウェアのみでの対処は難 しいと考えられるので, 張らの報告 ${ }^{11,12} に$ にるイオン交 換能を持つ資材の培養液中への混入や, 篠原らの報告 ${ }^{13)}$ にある重炭酸イオン濃度の能動的調整といった対策など 
を検討する必要があろう。この方法では $\mathrm{NO}_{3}-\mathrm{N}$ の吸収 が抑制され，カチオンの吸収が促進されるので， $\mathrm{pH}$ の 急激な低下が起こりにくいと考えられる，また，池田ら の報告 ${ }^{14)}$ では, $\mathrm{pH} 7$ の条件下では慣行施与濃度の窒素 分のうち半分までアンモニア態窒素に置き換えても地上 部乾物重に大きな差はなく, 植物体中の硝酸態窒素を低 濃度にすることが可能である。これらのことを踏まえ， よりイオン濃度制御に適した生育ステージ別培養液処方 が望まれる。

果実に関しては，収穫中期から後期にかけてイオン制 御区では $\mathrm{A}$ 品の, $\mathrm{EC}$ 制御区では $\mathrm{C}$ 品の収穫果数が増 加した. C 品は市場価値が無いにも関わらず担果負担は かかるため, 増加すると草勢低下を招きさらに生理障害 果が発生しやすくなる，これは収穫が進むにつれより顕 著となった. 摘果するとしても無駄な労力負担となる. それに対し，イオン濃度制御区では曲がりや生理障害果 の発生程度が小さく可販収量が増加し, 果実品質改善効 果が認められた。

以上のように培養液のイオン濃度制御法は従来の EC 制御法に比べ, 改良の余地はまだあるもののキュウリを はじめいろいろな作物の養液栽培において有効と考えら れ，他の作物でも検討中である.

\section{引用文献}

1）糠谷 明：オランダにおける排水の規制に関して, ハイドロポニックス, 5(1)：3-5(1991)

2) Papadopouls, A.P., Hao, X., Tu, J.C. and Zheng, J., Tomato production in open or closed rockwool culture system with NFT or rockwool nutrient feedings, ActaHorticulturae 481 : 89-96 (1999)

3）位田晴久, 久保田 豊, 田中豊秀：培養液調整の ための半自動プログラムの開発, 園学雑, 64(別 1) : 30-31 (1995)

4）位田晴久, 久保田 豊, 田中豊秀：培養液調整の ための半自動プログラムの開発(第 2 報)マンマシ
ンインターフェースの改良および演算時間の短縮 について，園学雑，64(別 2)：38-39(1995)

5）位田晴久, 久保田 豊, 田中豊秀：パソコンによ る培養液濃度の自動調節について, 日本植物工場 学会平成 8 年度大会学術講演要旨集, pp. 73-74 (1996)

6) Inden, H., Kubota, Y., Okamoto, K. and Kitahara, K. : Software for the automatic ion control of nutrient solutions, J. SHITA, 12(3) : 2227 (2000)

7）山崎肯哉, 鈴木芳夫, 篠原 温 : 主要そ菜の養液 栽培(水耕)に関する研究, 特に培養液管理とみか

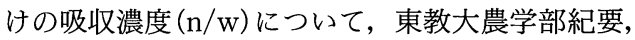
$22: 53-100(1976)$

8）但野利秋, 田中 明：アンモニア態および硝酸態 窒素適応性の作物種間差-1-生育初期におけるア ンモニア態および硝酸態窒素選択吸収能と生育反 応一比較植物栄養に関する研究, 土肥誌 47(7): 321-328(1976)

9）安井秀夫, 本田藤雄 : 野菜の生育制御に関する生 態学的研究-I 野菜の生長解析, 野菜試報告 C 3 : 17-50 (1977)

10）池田英男, 大沢孝也: 水耕培養液中の $\mathrm{NO}_{3}$ と $\mathrm{NH}_{4}$ の濃度並びに比率がそ菜の生育, 葉中 $\mathrm{N}$ 成 分及び培養液の $\mathrm{pH}$ に及ほす影響, 園学雑, 52 (2) : 159-166(1983)

11）張 洪基, 福山寿雄, 逸見彰男, 橋本 康: 人工 ゼオライト(アルカリ処理した石炭灰)の養液栽培 への有効利用 (第 2 報) - 温室メロンの育苗期にお ける $\mathrm{Ca}$ 型人工ゼオライト添加が生育に及ぼす影 響-，植物工場学会誌，7(4)：216-223(1995)

12）張洪 基, 福山寿雄, 逸見彰男, 橋本 康:メ口 ンの養液栽培に及ぼす各種イオン交換添加剤の影 響, 植物工場学会誌，8(1)：28-34(1996)

13）篠原 温, 正森啓司, 塚越 覚, 丸尾 達, 伊藤 正：養液栽培における培養液中の重炭酸イオンの 測定および調整の方法に関する研究, 千葉大園学 報，51：1-6(1997)

14）池田英男, 大沢孝也：施用窒素形態とそのそ菜の 適応性 (第 1 報) 水耕栽培において硝酸, アンモ二 ア，亜硝酸を窒素源とした果菜の生育並びに窒素 同化, 園学雑, 47(4)：454-462(1979) 